\title{
Evolution of the volcanic plumbing system of Alicudi (Aeolian Islands - Italy): evidence from fluid and melt inclusions in quartz xenoliths
}

\author{
Rossana Bonelli $\left({ }^{1}\right)$, Maria Luce Frezzotti $\left({ }^{1,2}\right)$, Vittorio Zanon $\left(^{3}\right)$ and Angelo Peccerillo $\left(^{3}\right)$ \\ ${ }^{1}$ ) Dipartimento di Scienze della Terra, Università degli Studi di Siena, Siena, Italy \\ ${ }^{(}{ }^{2}$ Istituto di Geologia Ambientale e Geoingegneria (IGAG) - CNR, Roma, Italy \\ $\left.{ }^{(}\right)$Dipartimento di Scienze della Terra, Università degli Studi di Perugia, Perugia, Italy
}

\begin{abstract}
Quartz-rich xenoliths in lavas (basalts to andesites; 90-30 ka) from Alicudi contain abundant melt and fluid inclusions. Two generations of $\mathrm{CO}_{2}$-rich fluid inclusions are present in quartz-rich xenolith grains: early (Type I) inclusions related to partial melting of the host xenoliths, and late Type II inclusions related to the fluid trapping during xenolith ascent. Homogenisation temperatures of fluid inclusions correspond to two density intervals: $0.93-0.68 \mathrm{~g} / \mathrm{cm}^{3}$ (Type I) and $0.47-0.26 \mathrm{~g} / \mathrm{cm}^{3}$ (Type II). Early Type I fluid inclusions indicate trapping pressures around $6 \mathrm{kbar}$, which are representative for the levels of partial melting of crustal rocks and xenolith formation. Late Type II fluid inclusions show lower trapping pressures, between $1.7 \mathrm{kbar}$ and $0.2 \mathrm{kbar}$, indicative for shallow magma rest and accumulation during ascent to the surface. Data suggest the presence of two magma reservoirs: the first is located at lower crustal depths (about $24 \mathrm{~km}$ ), site of fractional crystallization, mixing with source - derived magma, and various degrees of crustal assimilation. The second magma reservoir is located at shallow crustal depths (about $6 \mathrm{~km}$ ), the site where magma rested for a short time before erupting.
\end{abstract}

Key words Aeolian Islands - fluid inclusions crustal xenoliths - homogenisation temperature magma plumbing system

\section{Introduction}

Understanding the role of shallow level evolutionary processes in arc volcanoes has an important bearing on the way the various volcanoes work, which is a necessary preliminary

Mailing address: Dr. Rossana Bonelli, Dipartimento di Scienze della Terra, Università degli Studi di Siena, Via Laterina 8, I-53100 Siena, Italy; e-mail: bonelli5@unisi.it requirement to understand both the petrological (i.e. RACF processes) and volcanological evolution of magma. Modeling magma ascent rates, however, requires the determination of the residence depths of magma (i.e. location magmatic chambers) based on reliable geobarometers. Fluid and melt inclusion studies in magmatic minerals and/or in xenoliths entrained in volcanic rocks represent a valuable technique to reach this objective (e.g., Roedder, 1965; Clocchiatti et al., 1994; Andersen and Neumann, 2001). Many studies have shown that fluid inclusions may be abundant in lavas and xenoliths, reflecting composition, pressure and temperature conditions of the fluid phases trapped during magma ascent and degassing (see Andersen and Neumann, 2001). 
The Aeolian arc (southern Tyrrenian Sea) comprises seven volcanic Islands, some of which are active volcanoes (Vulcano, Stromboli, and, possibly, Lipari and Panarea) and six principal seamounts (Glauco, Sisifo, Enarete, Eolo, Lamatini and Alcione). Volcanic rocks range from mafic to acid and have calc-alkaline (CA), High-K Calc-Alkaline (HKCA), Shoshonitic (SHO) and potassic alkaline (KS) compositions, which are closely associated in time and space (see De Astis et al., 1997, 2000).

The Alicudi island is a composite volcano made up of dominant lavas and minor pyroclastic rocks of calcalkaline affinity sited at the western margin of the Aeolian arc. In spite of the many volcanological and geochemical studies carried out in recent decades, there is little or no information on the internal structure of Alicudi volcano and on the way the volcanic plumbing system works.

This paper presents fluid and melt inclusions data which contribute to the development of a model for the plumbing system of Alicudi, and for its evolution through time.

\section{Geological and volcanological setting}

The volcanism of the Aeolian archipelago initiated about one million years ago, generated by subduction of the Ionian plate under the Calabro-Peloritani continental margin (Barberi et al., 1973; Ellam et al., 1988). Alicudi is one of the youngest islands in the Aeolian arc $(90 \mathrm{ka}$; Gillot, 1987) located on the western side of the archipelago. The island represents the summit part of a complex stratovolcano, extending to $675 \mathrm{~m}$ above sea level and about $2000 \mathrm{~m}$ below (fig. 1). The overall circular pattern of its base (an area of about $5 \mathrm{~km}^{2}$ ) and the almost perfect conical shape of this stratovolcano suggests a development due to a central activity, without any significant migration of the feeding conduit (Villari, 1980).

According to several authors (Villari, 1980; Peccerillo and Wu, 1992; Peccerillo et al., 1993) Alicudi was built during three different subsequent volcanic cycles separated by caldera collapses (fig. 1). The first two cycles (Scoglio Galera, 90-60 ka and Dirittuso, $55 \mathrm{ka}$ )

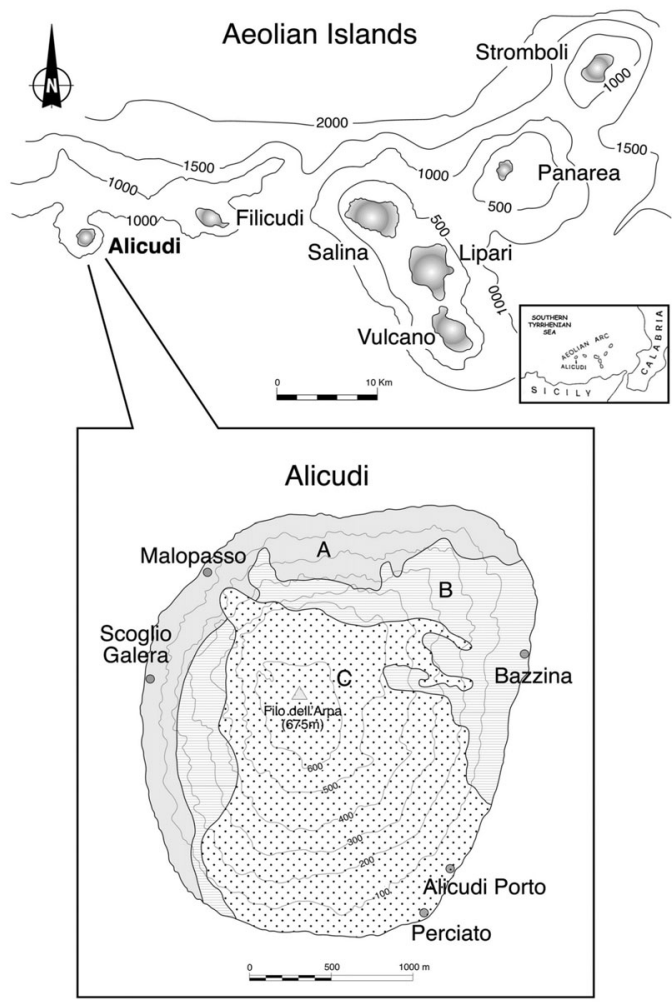

Fig. 1. Schematic geological map of Alicudi showing the volcanics belonging to the three different volcanic cycles, simplified from Manetti et al. (1989). A = first eruptive cycle - Scoglio Galera Formation ( 90-60 $\mathrm{ka}), \mathrm{B}=$ second eruptive cycle - Dirittuso Formation $(\sim 60 \mathrm{ka}), \mathrm{C}=$ third eruptive stage - Montagnola and Filo dell'Arpa Formation ( $28 \mathrm{ka})$. Grey dots indicate sampling localities.

were characterised by emission of calcalkaline basaltic and basalt-andesitic lavas and minor pyroclastic products. High-K andesitic lava flows and domes were emplaced during the third phase (Montagnole and Filo dell' Arpa, 28 $\mathrm{ka}$ ) from the summit crater on the southern flank of the volcano.

The volcanic products exhibit a restricted compositional range (from basalts to high-K andesite) and display the most primitive petrological and geochemical characteristics over the entire Aeolian arc (Peccerillo and Wu, 1992; Peccerillo et al., 1993). 


\section{Analytical methods}

Sample preparation for fluid inclusion studies was done by making doubly polished sections of 100-150 $\mu \mathrm{m}$ thickness. Microthermometry analyses were performed at the University of Siena with the Linkam TH600 heating and cooling Stage. SYNFLINC ${ }^{\circledR}$ standard synthetic fluid inclusions were used to calibrate the stage, checking the temperature at the $\mathrm{CO}_{2}\left(-56.6^{\circ} \mathrm{C}\right)$ and $\mathrm{H}_{2} \mathrm{O}\left(0^{\circ} \mathrm{C}\right)$ triple points. Accuracy at standard points was estimated $\pm 0.1^{\circ} \mathrm{C}$. Mac Flincor $^{\circledR}$ software package (Brown, 1989) with the equation of state by Holloway (1981) for $\mathrm{CO}_{2}$ were used to calculate the isochores for fluid inclusions. Density values of $\mathrm{CO}_{2}$ were calculated from Angus et al. (1976). Density of mixed inclusions of $\mathrm{CO}_{2}$ and $\mathrm{N}_{2}$ was derived from Kerkhof and Thièry (2001).

Fluid inclusions were further analysed with a confocal Labram multichannel spectrometer of Jobin-Yvon Ltd. in the laboratory of the University of Siena. The excitation line at $514.5 \mathrm{~nm}$ was produced by an $\mathrm{Ar}^{+}$laser. The Raman intensity was collected with a Poltier-cooled CCD detector. The beam was focused to a spot size of about $1-2 \mu \mathrm{m}$ using an Olympus $100 \times$ lens. The scattered light was analysed using a Notch holographic filter with a spectral resolution of $1.5 \mathrm{~cm}^{-1}$ and grating of 1800 grooves $/ \mathrm{mm}$.

Electron - microprobe analyses of mineral phases were performed with a Cameca SX 50 (IGAG-CNR, Roma) operated at an acceleration voltage of $15 \mathrm{kV}$ and a probe current of $15 \mathrm{nA}$. Mineral analyses were performed with a focused $(1 \mu \mathrm{m})$ beam. Natural and synthetic silicates were used as standards for mineral analyses.

Melt inclusions microthermometry of a single xenolith was performed at the Vrije University of Amsterdam using a high temperature (up to $1600^{\circ} \mathrm{C}$ ) heating/quenching stage (Sobolev and Kostyuk, 1975). Temperatures were measured with a Pt-Pt09Rh10 thermocouple, calibrated with gold, silver and synthetic compounds. Experiments were performed at $1 \mathrm{~atm} \mathrm{He}$, purified by a $700^{\circ} \mathrm{C}$ Ti filter. Heating times varied from 1 to 6 hours due to the slow kinetics of high-silica melts. Optimal heating rates of $2-5^{\circ} \mathrm{C} / \mathrm{min}$ were used above $700-900^{\circ} \mathrm{C}$ and much lower rates (5- $30^{\circ} \mathrm{C} /$ hour) near homogenisation temperature. Measurement uncertainties were estimated to be $\pm 5^{\circ} \mathrm{C}$. After quenching, host minerals were mounted on epoxy and polished until melt inclusions were exposed to surface. EMP analyses of melt inclusions were performed using a four-WDS-spectrometer JEOL Ltd. JXA 8800M Superprobe at the Vrije University of Amsterdam using an acceleration voltage of 15 $\mathrm{kV}$ and a beam current of $25 \mathrm{nA}$. Spot sizes were $2 \div 10 \mu \mathrm{m}$, with single-element counting times of $25 \div 50$ s on the peak and $10 \div 25 \mathrm{~s}$ on the bottom.

\section{Petrography of lavas and xenoliths}

Studied lavas and xenoliths were collected in three distinctive localities in Alicudi, which are considered representative of the overall petrological and volcanological evolution of the island (fig. 1):

1st cycle - basaltic lavas at Scoglio Galera and Malopasso (Scoglio Galera activity: 90$60 \mathrm{ka}$ );

2nd cycle - basaltic-andesitic lavas at Bazzina (Dirittuso activity: $\sim 55 \mathrm{ka}$ );

3rd cycle - andesitic lavas at the Alicudi Porto and Perciato (Montagnole and Filo dell'Arpa activity: $28 \mathrm{ka}$ ).

Xenoliths are particularly abundant in the basaltic lavas of the first two cycles, whereas they are scarce or absent in the third stage andesites.

\subsection{Host lavas}

The rocks of Alicudi are basalts, basaltic andesites and high-K andesites, which define a subalkaline trend showing transitional characters between calcalkaline and high-K calcalkaline according to the classification proposed by Peccerillo and Taylor (1976). Lavas are porphyritic, with plagioclase as the dominant phenocryst phase in all rock types, whereas olivine, although ubiquitous, is abundant (>30\%) only in basalts. Clinopyroxene phenocrysts occur in moderate amounts in all rocks. Representative mineral compositions of Alicudi lavas are reported in table Ia,b. 
Basalts from the first cycle of activity (Scoglio Galera) display a holocrystalline texture and a phenocryst content ranging from 30 to $50 \%$ of the total rock volume. Plagioclase makes up more than $50 \%$ of the total phenocryst abundance and consists of bytownite-labradorite $(\mathrm{An} \%=83-73$; table Ia). Olivine is also abundant $(\geq 30 \%)$ and occurs as phenocrysts $\left(\mathrm{Fo}_{79}\right)$ and microphenocrysts. Clinopyroxene occurs both as phenocrysts and in the groundmass and can be classified as augite (Wo\% $=40-43 ; \mathrm{En} \%=$ $=45-47$; Fs $\%=9-13$; table Ia).

Basaltic andesites from the second cycle of activity (Dirittuso) are porphyritic in texture and are similar to the basalts described above, but with less olivine $(\geq 20 \%)$. Plagioclase is by far the most abundant phenocryst phase and has compositions similar to those in the basalts, with $\max \mathrm{An} \%=81$ (not shown). Olivine $\left(\mathrm{FO}_{74}\right)$ and clinopyroxene $(\mathrm{Wo} \%=40-43 ; \mathrm{En} \%=45-47$; Fs $\%=9-13$ ) have compositions similar to those in the basalt. These two last minerals represent the principal phases in the groundmass as well.

High-K andesites from the third cycle of activity (Montagnole and Filo dell'Arpa) show porphyritic textures with dominant plagioclase phenocrysts of labradoritic composition (An\%= $=65-58)$. The olivine (Fo78-76) content is less than $20 \%$ and clinopyroxene shows a composition similar to that in basalts (Wo $\%=40 ;$ En $\%=$

Table Ia. Major (wt \%) elements of the studied phenocrysts in basaltic lavas of Alicudi.

\begin{tabular}{|c|c|c|c|c|c|c|c|c|c|}
\hline Samples & SG7 & TC5 & SG7 & SG7 & SG7 & SG7 & SG7 & SG7 & SG7 \\
\hline $\begin{array}{l}\text { mineral } \\
\text { note }\end{array}$ & OL & OL & CPX & CPX & CPX & $\begin{array}{l}\text { PL } \\
\text { core }\end{array}$ & $\begin{array}{l}\mathrm{PL} \\
\text { rim }\end{array}$ & $\begin{array}{l}\text { PL } \\
\text { core }\end{array}$ & $\begin{array}{l}\mathrm{PL} \\
\text { rim }\end{array}$ \\
\hline $\mathrm{SiO}_{2}$ & 38.69 & 36.98 & 52.31 & 51.42 & 52.52 & 47.53 & 48.46 & 47.88 & 49.76 \\
\hline $\mathrm{TiO}_{2}$ & - & - & 0.48 & 0.41 & 0.54 & - & 0.09 & 0.04 & - \\
\hline $\mathrm{Al}_{2} \mathrm{O}_{3}$ & - & - & 2.48 & 3.86 & 2.73 & 33.06 & 31.80 & 32.95 & 31.17 \\
\hline $\mathrm{Fe}_{\mathrm{O}}$ tot & 19.07 & 23.42 & 8.38 & 5.91 & 7.02 & 0.66 & 0.59 & 0.58 & 0.70 \\
\hline $\mathrm{MnO}$ & 0.28 & 0.44 & 0.18 & 0.07 & 0.14 & - & - & - & - \\
\hline $\mathrm{MgO}$ & 41.52 & 38.36 & 16.26 & 16.32 & 16.33 & - & - & - & - \\
\hline $\mathrm{CaO}$ & 0.18 & 0.25 & 19.94 & 20.88 & 21.03 & 17.06 & 16.18 & 16.99 & 14.91 \\
\hline $\mathrm{K}_{2} \mathrm{O}$ & - & - & 0.01 & - & - & 0.08 & 0.11 & 0.09 & 0.13 \\
\hline $\mathrm{Na}_{2} \mathrm{O}$ & - & - & 0.29 & 0.22 & 0.22 & 1.83 & 231 & 1.96 & 2.91 \\
\hline Totale & 99.74 & 99.44 & 100.33 & 99.09 & 100.53 & 100.22 & 99.54 & 100.48 & 99.57 \\
\hline Fo $\%$ & 79.50 & 74.48 & - & - & - & - & - & - & - \\
\hline $\mathrm{Fa} \%$ & 20.50 & 25.52 & - & - & - & - & - & - & - \\
\hline Wo\% & - & - & 40.48 & 43.25 & 42.61 & - & - & - & - \\
\hline En $\%$ & - & - & 45.94 & 47.07 & 46.05 & - & - & - & - \\
\hline Fs $\%$ & - & - & 13.58 & 9.68 & 11.34 & - & - & - & - \\
\hline $\mathrm{Mg}^{*}$ & 0.80 & 0.74 & 0.77 & 0.83 & 0.80 & - & - & - & - \\
\hline An $\%$ & - & - & - & - & - & 83.34 & 78.91 & 82.29 & 73.34 \\
\hline $\mathrm{Ab} \%$ & - & - & - & - & - & 16.17 & 20.42 & 17.19 & 25.87 \\
\hline Or\% & - & - & - & - & - & 0.49 & 0.66 & 0.52 & 0.79 \\
\hline
\end{tabular}

OL: olivine, CPX: clinopyroxene, PL: plagioclase; blank entries: not analysed; $\mathrm{Mg}^{*}=\mathrm{Mg} /\left(\mathrm{Mg}+\mathrm{Fe}_{\mathrm{TOT}}\right)$. 
Table Ib. Major (wt \%) elements of the studied phenocrysts in andesitic lavas of Alicudi.

\begin{tabular}{|c|c|c|c|c|c|c|c|c|c|}
\hline Samples & ARP & ARP & ARP & ARP & ARP & ARP & ARP & ARP & ARP \\
\hline $\begin{array}{l}\text { mineral } \\
\text { note }\end{array}$ & OL & OL & CPX & OPX & OPX & OPX & PL & $\begin{array}{l}\text { PL } \\
\text { core }\end{array}$ & $\begin{array}{l}\text { PL } \\
\text { rim }\end{array}$ \\
\hline $\mathrm{SiO}_{2}$ & 37.53 & 37.31 & 51.75 & 52.75 & 52.38 & 52.39 & 52.04 & 51.87 & 52.72 \\
\hline $\mathrm{TiO}_{2}$ & 0.01 & 0.03 & 0.45 & 0.22 & 0.30 & 0.20 & 0.06 & 0.01 & 0.06 \\
\hline $\mathrm{Al}_{2} \mathrm{O}_{3}$ & 0.04 & 0,03 & 1,78 & 0,97 & 0,80 & 1,45 & 30.33 & 30.47 & 29.00 \\
\hline $\mathrm{FeO}$ tot & 20.51 & 21.74 & 8.53 & 18.02 & 21.37 & 18.15 & 0.56 & 0.55 & 0.73 \\
\hline $\mathrm{MnO}$ & 0.40 & 0.42 & 0.36 & 0.66 & 0.95 & 0.83 & 0.02 & - & 0.03 \\
\hline $\mathrm{MgO}$ & 41.63 & 39.75 & 16.10 & 24.85 & 21.73 & 25.57 & 0.07 & 0.08 & 0.09 \\
\hline $\mathrm{CaO}$ & 0.18 & 0.25 & 20.37 & 2.02 & 1.90 & 1.32 & 13.20 & 13.11 & 11.83 \\
\hline $\mathrm{K}_{2} \mathrm{O}$ & 0.02 & 0.01 & 0.02 & 0.02 & 0.10 & 0.01 & 0.20 & 0.19 & 0.32 \\
\hline $\mathrm{Na}_{2} \mathrm{O}$ & - & 0.03 & 0.28 & 0.06 & 0.06 & 0.02 & 3.84 & 3.76 & 4.45 \\
\hline Totale & 100.32 & 99.57 & 99.64 & 99.57 & 99.59 & 99.94 & 100.32 & 100.04 & 99.23 \\
\hline Fo\% & 78.34 & 76.51 & - & - & - & - & - & - & - \\
\hline $\mathrm{Fa} \%$ & 21.66 & 23.49 & - & - & - & - & - & - & - \\
\hline Wo $\%$ & 0.24 & 0.34 & 40.96 & 3.94 & 3.83 & 2.55 & - & - & - \\
\hline En \% & 77.82 & 75.90 & 45.07 & 67.54 & 60.99 & 68.78 & - & - & - \\
\hline Fs $\%$ & 21.94 & 23.76 & 13.97 & 28.51 & 35.18 & 28.67 & - & - & - \\
\hline $\mathrm{Mg}^{*}$ & 0.78 & 0.76 & 0.76 & 0.70 & 0.63 & 0.71 & - & - & - \\
\hline An $\%$ & - & - & - & - & - & - & 64.75 & 65.09 & 58.38 \\
\hline $\mathrm{Ab} \%$ & - & - & - & - & - & - & 34.09 & 33.78 & 39.74 \\
\hline Or\% & - & - & - & - & - & - & 1.17 & 1.12 & 1.88 \\
\hline
\end{tabular}

OL: olivine, CPX: clinopyroxene, OPX: ortopyroxene, PL: plagioclase; blank entries: not analysed; $\mathrm{Mg}^{*}=$ $=\mathrm{Mg} /\left(\mathrm{Mg}+\mathrm{Fe}_{\mathrm{TOT}}\right)$.

$=45 ; \mathrm{Fs} \%=13$; table Ib). The groundmass contains the same phases as the phenocrysts, except olivine, set in glassy matrix.

\subsection{Quartz xenoliths}

The lavas of Alicudi commonly contain xenoliths of both magmatic and metamorphic origin, similar to observations in the other Aeolian Islands (e.g., Frezzotti et al., 2003). Metamorphic xenoliths show variable compositions and textures and can be classified as: i) quartz aggregates, ii) garnet-cordierite and garnet-sillimanite gneisses, iii) vesuvianite-grossular-bearing skarns and iv) metapelites (Honnorez and Keller, 1968; Peccerillo and $\mathrm{Wu}, 1992)$. Magmatic lithologies are represented by gabbros and diorites consisting of plagioclase and clinopyroxene.

Previous petrological and geochemical investigations suggest that metamorphic xenoliths represent residual material of partially melted gneiss and schists, thus constituting compelling field evidence of interaction between magma and crustal rocks beneath Alicudi volcano (Peccerillo and $\mathrm{Wu}, 1992$ ).

Study rocks consist of quartz xenoliths which contain abundant fluid and melt inclusions. Quartz xenoliths are composed mainly of quartz $(>95 \%)$, with accessory plagioclase, pyroxene, 
apatite, zircon and opaque (table II). They generally have angular shapes and sizes ranging from a few $\mathrm{mm}$ to a few dm. Quartz (400- $\mu \mathrm{m}-2 \mathrm{~mm})$ shows variable microstructural characteristics and is present both as rounded grains often rimmed by cristobalite (i.e. melting; fig. 2a), and as recrystallised crystal aggregates (i.e. annealing; fig. 2b). Significant quantities of internal glass, present both as intergranular veins and as short trails or clusters of silicate-melt inclusions, are often observed within single rounded quartz grains. Such a glass does not represent infiltration by host lavas since it has a distinctive high-silica rhyolitic composition.

\section{Melt inclusions}

Melt inclusions are present only in restitic quartz grains showing rounded morphology (fig. 2a). The dimensions of the inclusions vary according to their textural distribution. Their size is commonly about $30 \mu \mathrm{m}$, but inclusions of greater diameter were sometimes observed. Inclusions are commonly present isolated or in small clusters in most of the quartz grains (fig. 2c). Most melt inclusions contain glass and a bubble, \pm locally one or more crystals (quartz, feldspars, ilmenite, clinopyroxene, sulphides or oxides) are present in the glass. In some inclu-

Table II. Mineral compositions (wt \%) of studied quartz-rich xenoliths.

\begin{tabular}{|c|c|c|c|c|c|c|c|c|}
\hline Samples & TC3 & TC3 & TC5 & TC5 & TC5 & TC3 & TC3 & TC3 \\
\hline $\begin{array}{l}\text { Mineral } \\
\text { note }\end{array}$ & $\begin{array}{l}\text { CPX } \\
\text { core }\end{array}$ & CPX & OPX & OPX & OPX & $\begin{array}{l}\mathrm{PL} \\
\text { rim }\end{array}$ & $\begin{array}{c}\text { PL } \\
\text { core }\end{array}$ & $\begin{array}{l}\mathrm{PL} \\
\text { rim }\end{array}$ \\
\hline $\mathrm{SiO}_{2}$ & 54.73 & 52.99 & 52.51 & 50.54 & 51.39 & 54.52 & 53.40 & 53.39 \\
\hline $\mathrm{TiO}_{2}$ & - & 0.76 & 0.11 & - & 0.02 & - & - & - \\
\hline $\mathrm{Al}_{2} \mathrm{O}_{3}$ & 0.40 & 1.73 & 0.30 & 0.74 & 0.78 & 27.76 & 29.01 & 29.32 \\
\hline $\mathrm{FeO}$ tot & 2.60 & 4.44 & 24.23 & 24.72 & 21.85 & - & 0.51 & 0.38 \\
\hline $\mathrm{MnO}$ & - & 0.36 & 1.72 & 1.63 & 1.54 & - & - & - \\
\hline $\mathrm{MgO}$ & 17.18 & 16.84 & 20.84 & 21.38 & 22.68 & - & - & - \\
\hline $\mathrm{CaO}$ & 24.61 & 22.77 & 0.97 & 0.22 & 0.40 & 11.08 & 12.42 & 12.56 \\
\hline $\mathrm{Na}_{2} \mathrm{O}$ & 0.17 & 0.31 & 0.01 & 0.03 & - & 5.19 & 4.43 & 4.17 \\
\hline $\mathrm{K}_{2} \mathrm{O}$ & - & - & - & 0.02 & 0.02 & 0.37 & 0.34 & 0.31 \\
\hline Totale & 99.69 & 100.20 & 100.69 & 99.28 & 98.68 & 98.92 & 100.12 & 100.12 \\
\hline Wo $\%$ & 48.68 & 45.57 & 1.93 & 0.43 & 0.80 & - & - & - \\
\hline En $\%$ & 47.30 & 46.92 & 57.71 & 58.83 & 62.81 & - & - & - \\
\hline Fs $\%$ & 4.02 & 7.51 & 40.36 & 40.73 & 36.39 & - & - & - \\
\hline $\mathrm{Mg}^{*}$ & 0.92 & 0.86 & 0.59 & 0.59 & 0.63 & - & - & - \\
\hline An $\%$ & - & - & - & - & - & 52.96 & 59.60 & 61.37 \\
\hline $\mathrm{Ab} \%$ & - & - & - & - & - & 44.93 & 38.47 & 36.83 \\
\hline Or $\%$ & - & - & - & - & - & 2.11 & 1.93 & 1.79 \\
\hline
\end{tabular}

CPX: clinopyroxene, OPX: ortopyroxene, PL: plagioclase; blank entries: not analysed; $\mathrm{Mg}^{*}=\mathrm{Mg} /(\mathrm{Mg}+$ $\left.+\mathrm{Fe}_{\text {TOT}}\right)$. 

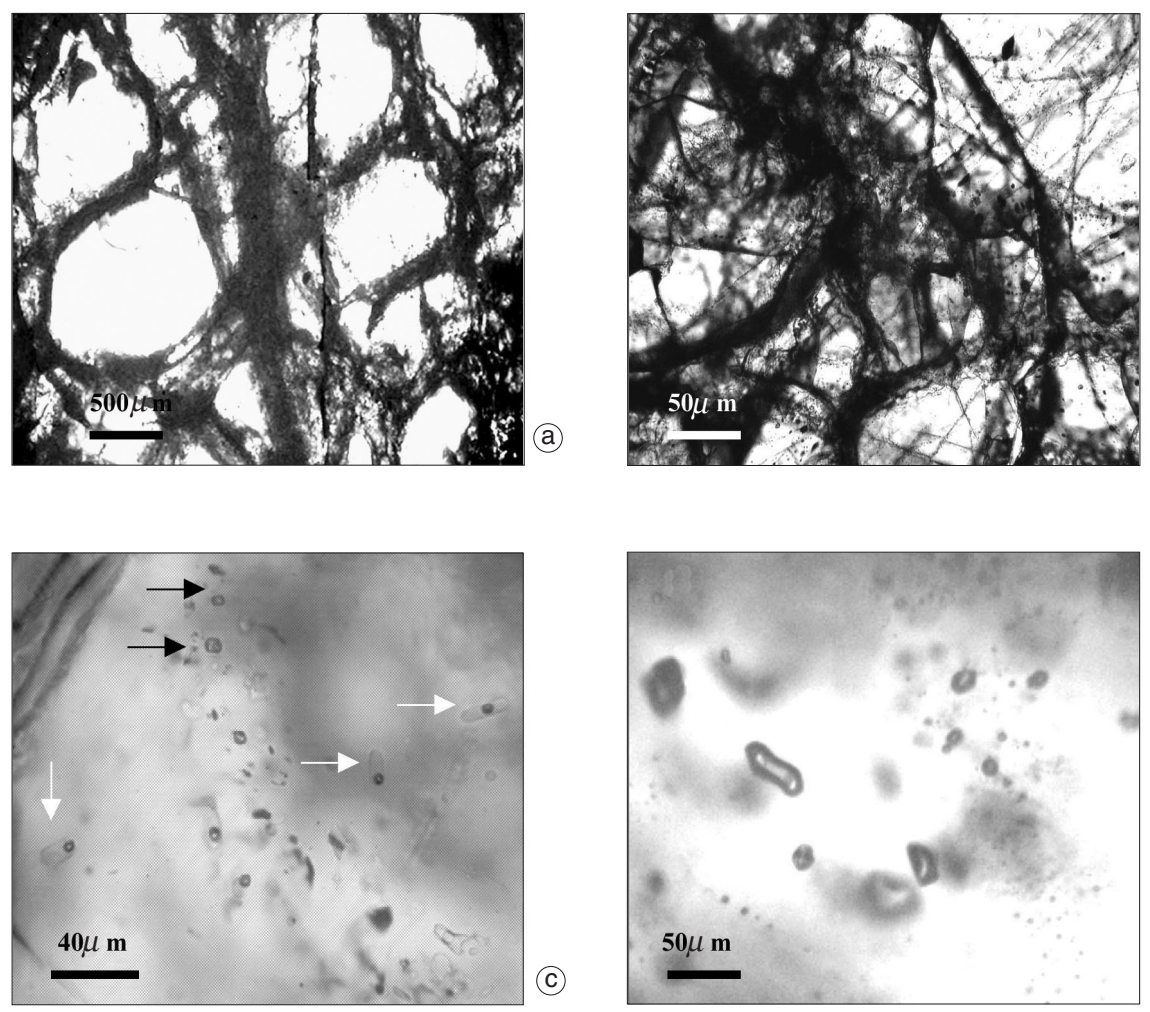

(d)
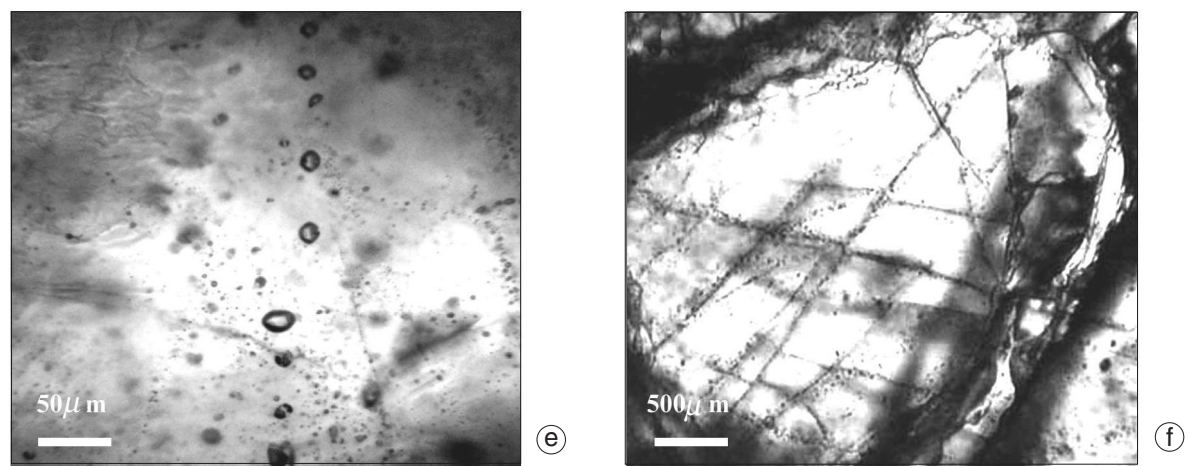

Fig. 2a-f. Photomicrographs of studied quartz xenoliths and fluid inclusions: a) and b) quartz grain textures in a quartz xenolith from a basaltic rock of the 1st cycle of Alicudi (Scoglio Galera): a) this type of quartz is transparent and generally has a rounded contour; b) this type of quartz is milky, highly fractured with cracks filled with trails secondary fluid inclusions; c) trail of texturally early Type I fluid inclusions in a quartz grain (Scoglio Galera). Type I fluid inclusions (black arrows) occur associated with silicate - melt inclusions (white arrows); d) cluster of early Type I inclusions in a quartz grain from Dirittuso; e) trail of late Type II fluid inclusions in a quartz grain from Dirittuso. These inclusions are clearly secondary origin and contain $\mathrm{CO}_{2}$; f) late trails of Type II $\mathrm{CO}_{2}$ inclusions distributed along two main directions in a quartz grain (Scoglio Galera). 
sions, a large bubble is present, often containing immiscible $\mathrm{CO}_{2}$. The presence of $\mathrm{CO}_{2}$ in melt inclusions is associated with the $\mathrm{CO}_{2}$-rich fluid in host xenolith.

Homogenisation temperatures of silicate-melt inclusions are between 1060 and $1120 \pm 5^{\circ} \mathrm{C}$.

The glass consists of $\mathrm{SiO}_{2}(69-78$ wt. $\%)$, $\mathrm{Al}_{2} \mathrm{O}_{3}$ (10-11 wt.\%), $\mathrm{K}_{2} \mathrm{O}$ (3-5 wt.\%), $\mathrm{Na}_{2} \mathrm{O}$ (12 wt.\%) and very little or no $\mathrm{FeO}, \mathrm{MgO}$ (chemical data from four melt inclusions are reported in table III).

\section{Fluid inclusions}

\subsection{Composition and distribution}

Fluid inclusions from studied xenoliths melt instantaneously in a narrow $T$ interval $(-56.9 \div$

Table III. Results of electron - microprobe analyses of silicate - melt inclusion in a quartz xenolith of Alicudi.

\begin{tabular}{lrrrr}
\hline \hline Samples & ARP & ARP & ARP & ARP \\
\hline $\mathrm{SiO}_{2}$ & 78.10 & 72.60 & 69.00 & 75.10 \\
$\mathrm{TiO}_{2}$ & 0.18 & 0.11 & 0.87 & 0.02 \\
$\mathrm{Al}_{2} \mathrm{O}_{3}$ & 10.30 & 11.60 & 11.20 & 11.60 \\
$\mathrm{Cr}_{2} \mathrm{O}_{3}$ & 0.01 & 0.00 & 0.02 & 0.02 \\
$\mathrm{Fe}_{2} \mathrm{O}_{3}$ & 0.23 & 0.98 & 1.78 & 0.34 \\
$\mathrm{FeO}$ & 0.47 & 1.97 & 3.56 & 0.69 \\
$\mathrm{MnO}$ & 0.03 & 0.09 & 0.08 & 0.05 \\
$\mathrm{MgO}$ & 0.20 & 0.72 & 1.68 & 0.16 \\
$\mathrm{CaO}$ & 0.48 & 2.14 & 3.89 & 0.69 \\
$\mathrm{Na}_{2} \mathrm{O}$ & 1.72 & 1.67 & 1.17 & 1.91 \\
$\mathrm{~K}_{2} \mathrm{O}$ & 4.67 & 3.97 & 3.33 & 4.96 \\
$\mathrm{P}_{2} \mathrm{O}_{5}$ & 0.00 & 0.00 & 0.29 & 0.00 \\
$\mathrm{SO}$ & 0.00 & 0.03 & 0.00 & 0.00 \\
$\mathrm{~F}$ & 0.03 & 0.04 & 0.01 & 0.10 \\
$\mathrm{Cl}$ & 0.23 & 0.48 & 0.00 & 0.28 \\
$\mathrm{Totale}_{3}$ & 96.65 & 96.40 & 96.88 & 95.92 \\
\hline & & & &
\end{tabular}

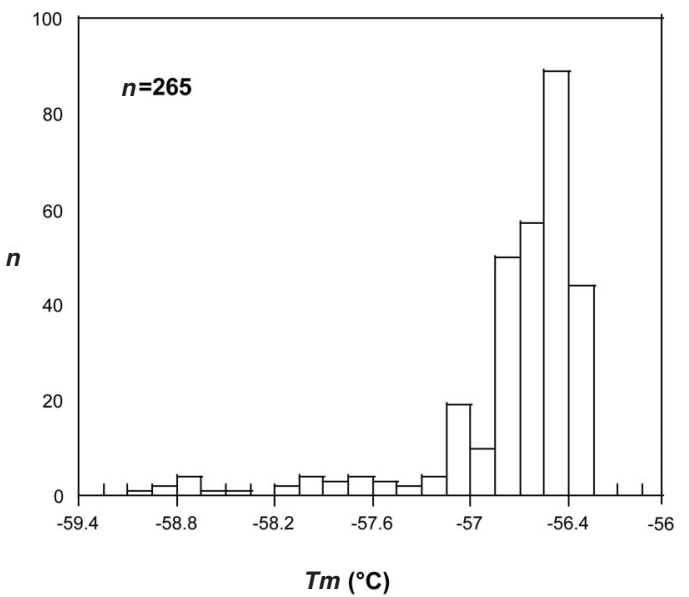

Fig. 3. Histogram of melting temperatures $(\mathrm{Tm})$ for studied fluid inclusions. Most $\mathrm{CO}_{2}$ melting occurs within a narrow temperature interval between -56.9 and $-56.3^{\circ} \mathrm{C}$ (maximum at $-6.6^{\circ} \mathrm{C}$ ).

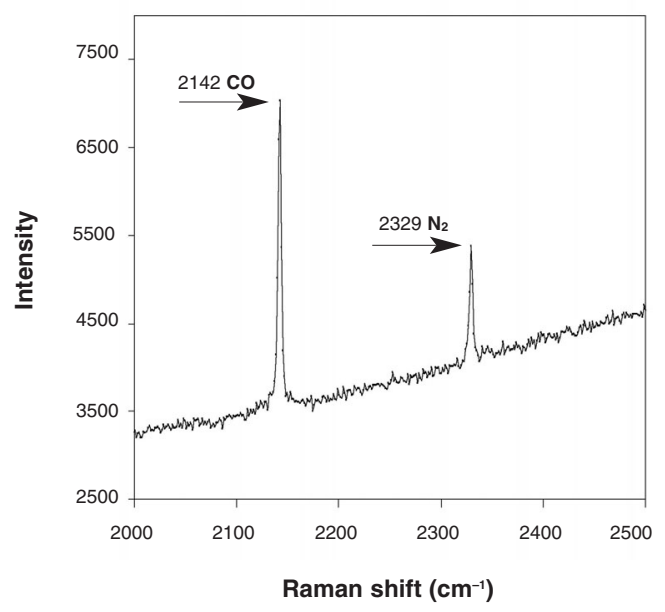

Fig. 4. Raman spectrum for a fluid inclusion in a quartz xenolith from Scoglio Galera. The inclusion contains nitrogen (10 mole\%) and carbon monoxide (14 mole\%) besides $\mathrm{CO}_{2}$.

$\div-56.3$; highest frequency $T m=-56.6$; fig. 3 ), suggesting that $\mathrm{CO}_{2}$ is the major phase present. Raman spectra (28 collected) reveal the presence of other species (table IV). Nitrogen (1-10 mole\%) 
Table IV. Chemical composition of fluid inclusions from Raman and microthermometric measurements.

\begin{tabular}{|c|c|c|c|c|c|c|}
\hline Samples & $\begin{array}{l}T h_{L} \\
\left({ }^{\circ} \mathrm{C}\right)\end{array}$ & $\begin{array}{r}T h_{v} \\
\left({ }^{\circ} \mathrm{C}\right)\end{array}$ & $\begin{array}{r}T m \\
\left({ }^{\circ} \mathrm{C}\right)\end{array}$ & $\begin{array}{r}\mathrm{CO}_{2} \\
(\text { mole \%) }\end{array}$ & $\begin{array}{r}\mathrm{N}_{2} \\
\text { (mole \%) }\end{array}$ & $\begin{array}{r}\mathrm{CO} \\
(\text { mole } \%)\end{array}$ \\
\hline \multicolumn{7}{|c|}{$1^{\circ}$ Cycle of Scoglio Galera (90-60 ka) } \\
\hline SG1 d)bis* & - & 16.5 & -57.9 & 90 & 2 & 8 \\
\hline SG1 d)bis & - & 17.0 & -58.0 & 92 & 1 & 7 \\
\hline SG1 d)bis & - & 15.0 & -58.1 & 82 & 4 & 14 \\
\hline SG1 d)bis & - & 17.6 & -57.9 & 92 & 2 & 6 \\
\hline SG10 d)2 & 5.0 & - & -57.7 & 95 & 5 & - \\
\hline SG10 d)2 & - & 24.0 & -57.0 & 97 & 3 & - \\
\hline SG7 a)1 & - & 0.5 & -57.0 & 97 & 3 & - \\
\hline SG7 f) & 16.6 & - & -57.5 & 96 & 4 & - \\
\hline \multicolumn{7}{|c|}{$2^{\circ}$ Cycle of Dirittuso (55 ka) } \\
\hline TC5a) & 22.0 & - & -57.2 & 97 & 3 & - \\
\hline TC5c) & -2.5 & - & -58.9 & 90 & 10 & - \\
\hline TC5e) & 8.8 & - & -57.3 & 98 & 1 & 1 \\
\hline TC5f) & 4.5 & - & -58.1 & 94 & 6 & - \\
\hline TC5f) & 4.5 & - & -58.5 & 94 & 6 & - \\
\hline TC5f) & 0.8 & - & -58.7 & 93 & 7 & - \\
\hline TC5f) & 16.3 & - & -57.8 & 96 & 4 & - \\
\hline TC5f) & 5.2 & - & -58.9 & 95 & 5 & - \\
\hline TC5f) & 7.0 & - & -58.7 & 95 & 5 & - \\
\hline TC1-1a)1 & 20.2 & - & -57.1 & 97 & 3 & - \\
\hline TC1-1a)1 & 20.0 & - & -57.1 & 97 & 3 & - \\
\hline TC1-1a)2 & - & 23.5 & -57.0 & 97 & 3 & - \\
\hline TC1-1b) & - & 25.5 & -57.0 & 97 & 3 & - \\
\hline TC1-1c) & 27.0 & - & -57.1 & 98 & 2 & - \\
\hline TC1-1c) & - & 29.0 & -57.1 & 98 & 2 & - \\
\hline TC1-1c) & - & 23.0 & -57.2 & 97 & 3 & - \\
\hline TC1-1c) & - & 23.5 & -57.2 & 97 & 3 & - \\
\hline
\end{tabular}

* Raman spectrum (fig. 4).

\pm carbon monoxide (1-14 mole\%) are always present in fluid inclusions with melting below $-56.9^{\circ} \mathrm{C}$ and slow melting behaviour (fig. 4; table IV).

Carbon dioxide is present in two different generations of inclusions:

Type I - early inclusions are present in xenoliths of the 1 st and 2 nd cycles (fig. 2c,d). They are isolated or in a small clusters with sizes ranging $3 \div 10 \mu \mathrm{m}$ and shapes generally regular. Partial decrepitation is visible (haloes of small inclusions around the inclusion cavity) (Anderson et al., 1984). Early inclusions are often associated with silicate-melt inclusions suggesting concomitant trapping.

Type II - late inclusions are present in all studied xenoliths and occur in variable shape and size. They are distributed along inter- and intragranular trails (fig. 2e,f). Only a few among late Type II inclusions show evidence of partial decrepitation. 


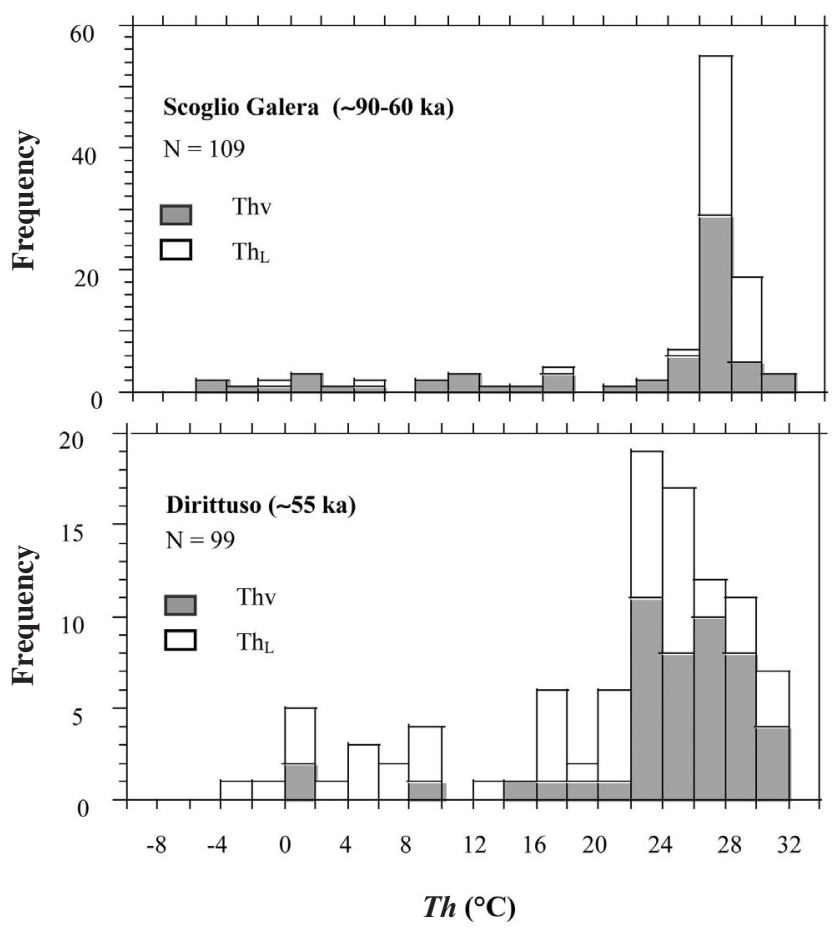

Fig. 5. Histograms of homogenisation temperatures for fluid inclusions present in xenoliths of the studied volcanic island (Alicudi). Histograms report homogenisation temperatures to the liquid phase $\left(T h_{L}\right)$ for early Type I fluid inclusions and homogenisation temperatures to the vapour phase $\left(T h_{V}\right)$ for late Type II fluid inclusions.

\subsection{Homogenisation temperatures and fluid density calculations}

Quartz xenoliths from Scoglio Galera and Dirittuso contain high-density (fig. 2c,d) and low-density (fig. 2e,f) fluid inclusions - Type I and Type II inclusions, respectively. The distribution of fluid inclusions from Filo dell'Arpa is different. Here, inclusions are extremely rare and all of Type II.

Scoglio Galera (1st cycle of activity; $\sim 90 \mathrm{ka}$ ): Type I inclusions always homogenise to liquid $\left(T h_{L}\right)$ in an interval of temperatures between -0.5 and $29.5^{\circ} \mathrm{C}$ (fig. $5)$, with calculated density values between 0.93 and $0.61 \mathrm{~g} / \mathrm{cm}^{3}$. Most $T h_{L}$ values, clustering around $28^{\circ} \mathrm{C}$, represent re-equilibrated fluid inclusions (decrepitation; Vityk and Bodnar, 1998).
Type II inclusions homogenise to vapour $\left(T h_{V}\right)$ in the range of temperatures between -6 and $31^{\circ} \mathrm{C}$, with corresponding density values between 0.08 and $0.47 \mathrm{~g} / \mathrm{cm}^{3}$. The $T h_{V}$ histogram shows a few data scattered in a wide range of re-equilibrated inclusions.

Dirittuso (2nd cycle of activity; $\sim 55 \mathrm{ka}$ ): microthermometric data for early Type I inclusions show a distribution of temperatures between $-2.5^{\circ} \mathrm{C}$ and $31.1^{\circ} \mathrm{C}$, with resulting density values between 0.93 and $0.47 \mathrm{~g} / \mathrm{cm}^{3}$ (the lowest temperatures around $-2.5^{\circ} \mathrm{C}$ to belong to a $\mathrm{CO}_{2}+\mathrm{N}_{2}$ fluid inclusion, with density value of $0.83 \mathrm{~g} / \mathrm{cm}^{3}$ ) (fig. 5). Values between 22 and $31^{\circ} \mathrm{C}$ belong to re-equilibrated inclusions. Type II vapour-rich inclusions show homogenisation temperatures between 0 and $31^{\circ} \mathrm{C},\left(d=0.10_{-}\right.$ $0.47 \mathrm{~g} / \mathrm{cm}^{3}$ ). Lowest $\mathrm{Th}_{\mathrm{V}}$ values, below $26^{\circ} \mathrm{C}$, correspond to re-equilibrated fluid inclusions. 
Filo dell'Arpa (3rd cycle of activity; 28 $\mathrm{ka})$ : this cycle is represented by two low-density inclusions $\left(T h_{V}\right)$, with homogenisation temperatures between 6 and $18^{\circ} \mathrm{C}$. Density values are between 0.12 and $0.18 \mathrm{~g} / \mathrm{cm}^{3}$.

\section{Discussion}

\subsection{Isochore calculation}

Isochoric lines representative for $P$ and $T$ conditions of fluid trapping in xenoliths during ascent of lavas for the different volcanic cycles are reported in fig. 6. The figure shows the presence of two isochoric bands, corresponding to the bimodal distribution of density values for the different inclusion types. The narrowest interval is between 0.47 and $0.26 \mathrm{~g} / \mathrm{cm}^{3}$, corresponding to Type II low-density inclusions; the other interval (between 0.93 and $0.68 \mathrm{~g} / \mathrm{cm}^{3}$ ) corresponds to Type I high-density fluid inclusions. Note that this last isochoric band is much wider due to the presence of density data from reequilibrated inclusions. Not all of the fluid inclusion densities observed in xenoliths reflect original densities at trapping conditions: most Type I fluid inclusions show textural evidence for decrepitation and fluid density decrease. Decrepitation is confirmed by the frequent presence of small haloes of tiny bubbles and/or little fractures around the inclusions, and by the scattered $T h$ distribution. Reset density data for Type I inclusions will not be considered in the following discussion.

\subsection{Temperature and pressure estimates}

Before any meaningful geological interpretation can be proposed it is necessary: first to fully describe the temperature and pressure conditions under which Type I and Type II $\mathrm{CO}_{2}$ fluids are trapped, and second to verify the fluid-xenoliths evolution during ascent. The temperature conditions for the fluids at the time of trapping are based on homogenisation temperatures of silicate melt inclusions, since
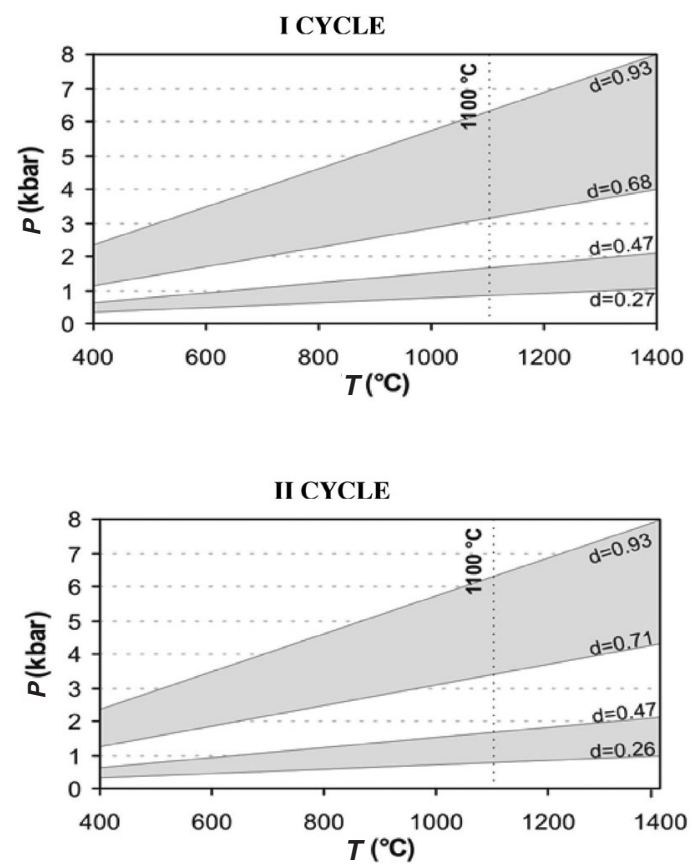

Fig. 6. Isochoric bands, corresponding to the bimodal distribution of densities for the first two magmatic cycles of activity of the Alicudi island: the first at high pressure corresponding to early Type I fluid inclusions and the latter at shallower pressures corresponding to late Type II fluid inclusions, see text.

microstructural evidence clearly indicates concomitant trapping of high-silica melt and (Type I) $\mathrm{CO}_{2}$ fluids in the inclusions.

Homogenisation temperatures of silicatemelt inclusions show values between 1060 and $1120^{\circ} \mathrm{C}\left( \pm 5^{\circ} \mathrm{C}\right)$. For this reason, we assume $1100^{\circ} \mathrm{C}$ as a mean trapping temperature for fluid inclusions present in xenoliths.

At $1100^{\circ} \mathrm{C}$, pressure estimates from fluid inclusions form two distinct pressure intervals that are interpreted to reflect two different episodes of fluid entrapment. Both undisturbed early Type I inclusions from the 1st cycle of Scoglio Galera and from the 2nd cycle of Dirittuso show identical maximum pressure estimates at $\approx 6$ kbar. Such a pressure corresponds to a depth of about $24 \mathrm{~km}$, assuming $2.7 \mathrm{~g} / \mathrm{cm}^{3}$ as the average 
value of density for the stratigraphic sequence beneath Alicudi (Zanon, 2001).

A second episode of fluid trapping in quartz xenoliths from lavas of both the 1 st and 2 nd cycles occurred at a later stage, and is represented by low-density Type II inclusions. Type II fluid inclusions indicate similar pressure values and between 1.7 and $0.2 \mathrm{kbar}$ (about $6 \mathrm{~km}$ depth).

For Filo dell'Arpa andesitic lavas (3rd cycle), low-density Type II inclusions form a distinct pressure interval, between 0.5 and $0.3 \mathrm{kbar}$ (about $1 \mathrm{~km}$ depth).

\subsection{Polybaric evolution of Alicudi's magmas}

The data obtained from the study of fluid and melt inclusions hosted in quartz-rich xenoliths allow us to propose a schematic model for the plumbing system of Alicudi volcano, and to describe its modification through time, illustrated in fig. 7a-c. Fluid inclusion barometry bear evidence that basaltic and basaltic andesitic lavas of the first and second cycles (Scoglio Galera, $90 \mathrm{ka}$ and Dirittuso, $55 \mathrm{ka}$ ) underwent the same polybaric evolution in the crust. Type I fluid inclusion data for the first two volcanic cycles indicate that a deep magma storage level has been present beneath the island, located at lower-crustal depths (about $24 \mathrm{~km}$; fig. $7 \mathrm{a}, \mathrm{b})$, since the Moho beneath Alicudi island was proposed at $21-25 \mathrm{~km}$ (Falsaperla et al., 1984). Such a magma accumulation level probably corresponds to a deep magma chamber located at the crust-mantle boundary, where mantle magmas rested and underwent contamination and very limited crystal fractionation.

Barometric data from low-density Type II fluid inclusions indicate that a second magma storage level is present located at shallower depths (about $6 \mathrm{~km}$ ). Shallow level magma chambers are fed by the deep magma chambers. The occurrence of quartz xenoliths, which contain both low-density (Type I) and high-density (Type II) fluids, the lack of extensive density resetting for Type I deep fluids, and the preservation of quartz xenoliths themselves, all suggest that the residence time of deep magmas and related quartz xenoliths in the shallow chambers is very short, possibly a few days. Thus, we can conclude that a single volcanic plumbing system was active during the first two cycles, and from 90 to $55 \mathrm{ka}$, related to the eruption of basaltic and basaltic andesite lavas (fig. 7a,b). The above model implies that the large quantities of mafic magmas which characterise the first two cycles of the activity of Alicudi reflect tapping of deep level reservoirs, where dominant mixing processes do not allow magma differentiation toward silicic composition.

According to fluid inclusion data, the overall magma ascent evolution shows abrupt variations during the third cycle. For late andesitic lavas of Filo dell'Arpa, inclusion evidence indicates that a deep magma chamber is conspicuously absent (fig. 7c). A single magma accumulation level is indicated by Type II low density fluid inclusions at about $1 \mathrm{~km}$ depth; that is more superficial than those present during the first two cycles (compare fig. 7a,b with fig. 7c).

It would be inaccurate, however, to propose a model for andesite crustal evolution based only on fluid inclusion evidence. The absence of Type I inclusions and the limited amount of Type II inclusions in quartz xenoliths contained in andesitic lavas might be related to the scarcity of studied samples, since andesites do not contain abundant metamorphic rocks. Higher viscosity and lower temperatures of such lavas compared to previous basaltic ones may have prevented melting and incorporation of crustal rocks within the ascending magma. For these reasons, we cannot exclude that andesites formed in the same deep magma chambers where early stages basalts and basaltic andesites rested resulting a similar polybaric evolution.

\section{Concluding remarks}

Present fluid inclusions data indicate that two principal levels of magma accumulation were present beneath the island during the first two cycles (Scoglio Galera and Dirittuso), indicating a polybaric evolution for Alicudìs magmas.

A first deep accumulation level is present at depths close to the Moho $(\sim 24 \mathrm{~km})$. At these stages xenoliths were possibly trapped along with (Type I) $\mathrm{CO}_{2} \pm \mathrm{N}_{2} \pm \mathrm{CO}$ fluids in the basaltic lavas. 

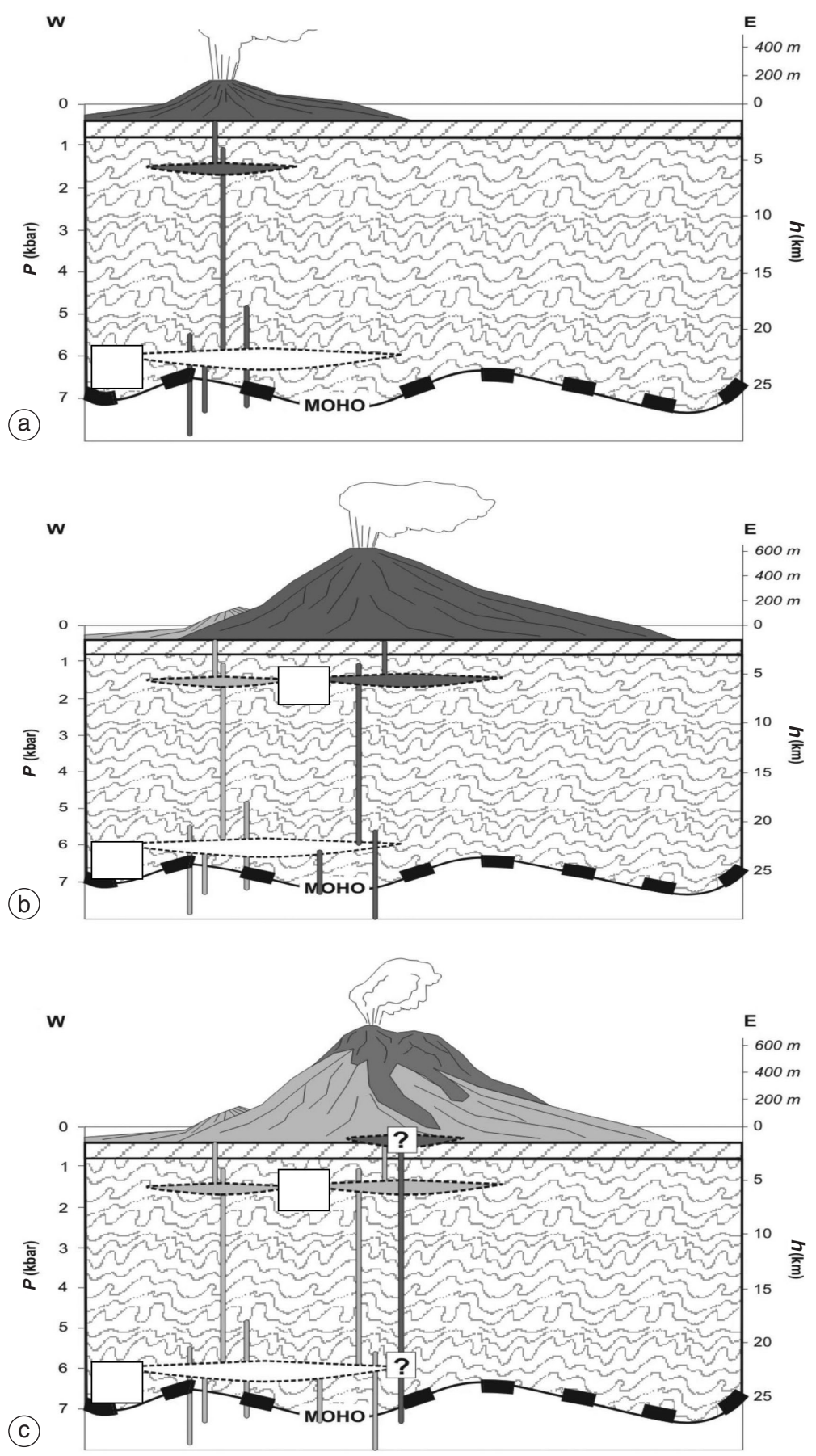

Fig. 7a-c. Schematic section modelling the magma plumbing system beneath Alicudi island, as inferred from fluid inclusion study. Lithological boundaries are from Falsaperla et al., 1984 (see text). 
A second magma storage level at upper crustal depths (about $6 \mathrm{~km}$ ) has been active throughout the volcanic history of the island. Here magmas and xenoliths rested for a time span sufficient for new $\mathrm{CO}_{2}$ fluid trapping (Type II) and old Type I fluid inclusion density resetting.

It is noteworthy that during the 3rd cycle, when magma compositions were more evolved (andesites) there is no evidence from fluid inclusions for a deep accumulation level.

\section{Acknowledgements}

The authors are grateful to C. Ghezzo for useful suggestions and comments and to $\mathrm{G}$. Cavarretta and M. Serracino for hosting R.B. and for EDS analytical facilities at the IGAG Studio del Quaternario e dell'Evoluzione Ambientale - CNR. V.Z. acknowledges W. Lustenhower and I. Nikogosian for help during his stay at the V.U. in Amsterdam. Raman facilities were provided by PNRA, the Italian Organisation for Scientific Research in Antarctica.

\section{REFERENCES}

ANDERSEN, T., S.Y. O'REILlY and W.L. GRIFFIN (1984): The trapped fluid phase in upper mantle xenoliths from Victoria, Australia: implications for mantle metasomatism. Contrib. Miner. Petrol., 88, 72-85.

Andersen, T. and E.R. NeumanN (2001): Fluid inclusions in mantle xenoliths, in Fluid Inclusion Studies-Principles and Applications, edited by T. ANDERSEN, M.L. FrezzotTI and E. BuRKe, Lithos, 55, 301-320.

Angus, S., B. Armstrong, K.M. De Reuck, V.V. Altunin, O.G. Gadetskit, G.A. Chapela and J.S. Rowlinson (1976): Carbon dioxide, in International Tables of the Fluid State, vol. 3 (Pergamon Press, Oxford)

Barberi, F., P. Gasparini, F. InNOCENTI and L. Villari (1973): Volcanism of the Southern Tyrrhenian Sea and its geodinamic implication, J. Geophys. Res., 78 (23), 5221-5232.

BROwN, P.E. (1989): FLINCOR: a fluid inclusion data reduction and exploration program, in Second Biennal Pan-Am Conf Fluid Inclusions Program Abst., pp. 14.

Clocchiatti, R., A. Del Moro, A. Gioncada, J.L. Joron, M. Mosbah, L. Pinarelli and A. Sbrana (1994): Assessment of a shallow magmatic system: the 1888-90 eruption, Vulcano Island, Italy, Bull. Volcanol., 56, 466-486.

De Astis, G., L L a Volpe, A. PECCERILlo and L CivetTA (1997): Volcanological and petrological evolution of Vulcano island (Aeolian Arc, Southern Tyrrhenian Sea), J. Geophys. Res., 102, 8021-8050.
De Astis, G., A. Peccerillo, P.D. Kempton, L. La Volpe and T.W. Wu (2000): Transition from calc-alkaline to potassium-rich magmatism in subduction environments: geochemical and $\mathrm{Sr}, \mathrm{Nd}, \mathrm{Pb}$ isotopic constraints from the Island of Vulcano (Aeolian arc), Contrib. Mineral. Petrol., 139, 684-703.

Ellam, R.M., M.A. MenZies, C.J. Hawkesworth, W. LEEMAN, M. Rosi and G. SERRI (1988): The transition from calc-alcaline to potassic orogenic magmatism in the Aeolian Islands, Southern Italy, Bull. Volcanol., 50, 386-398.

FAlsaperla, S., G. Neri and S. Velardita (1984): Struttura della crosta superiore nell' area delle isole Eolie, Rendiconti dell'Osservatorio Geofisico Reggino, 29, 103-111.

Frezzotti, M.L., A. Peccerillo, V. Zanon and R. BonelLI (2003): Magma ascent rates and depths of magma reservoirs beneath the aeolian volcanic arc (Italy): inferences from fluid and melt inclusions in crustal xenoliths, in Melt Inclusions in Volcanic Systems, edited by B. BodNAR and B. DE VIVO (Elsevier), (185-206).

GILLOT, P.Y. (1987): Histoire volcanique des Iles Eoliennes: arc insulaire ou complexe orogenique annulaire?, Doc. Trav. IGAL., 11, 35-42.

HoLLOWAY, J.R. (1981): Compositions and volumes of supercritical fluids in the earth's crust, in MAC Short Course in Fiuid lnclusions, edited by L.S. ROLLISTER and M.L. CRAWFORD (Mineralogical Association of Canada), 13-38.

HONNOREZ, J. and J. KeLLER (1968): Xenolithe in vulkanischen Gesteiner der Àolischen Inseln (Sizilien), Geologischen Rundschau., 57, 719-736.

KerkHof, A.M. VAN Den and R. ThIERY (2001): Carbon inclusions, in Fluid Inclusions: Phase RelationshipsMethods-Applications, edited by T. ANDERSEN, M.L. FrezzotTI and E. Burke, Lithos, 55, 49-69.

Manetti P., G. Pasouarè, A. Tibaldi and A. Tsegaye (1989): Geologia dell'Isola di Aliendi (Eolie), Boll. G.N.V., 2, 903-916.

PECCERILlO, A. and S.R. TAYLOR, (1976): Geochemistry of Eocene calcalkaline volcanic rocks from Kastamonu area, northern Turkey, Contrib. Miner. Petrol., 56, 221-246.

Peccerillo, A. and T.W. Wu (1992): Evolution of calcalkaline magmas in continental arc volcanoes: evidence from Alicudi, Aeolian arc (Southern Tyrrhenian Sea, Italy), J. Petrol., 33 (6), 1295-1315.

Peccerillo, A., D. Kempton, R. Harmon, T.W. Wu, A SAnto, A.J. Boyce and A. TRIPOdo (1993): Petrological and geochemical. characteristics of the Alicudi volcano, Aeolian islands, Italy: implications for magma genesis and evolution, Acta Vulcanol., 3, 235-249.

ROEDDER, E. (1965): Liquid $\mathrm{CO}_{2}$ inclusions in olivine-bearing nodules and phenocrysts from basalts, Am. Mineral., 50, 1746-1782.

Sobolev, V.S. and V.P. Kostyuk (1975): Magmatic crystallization based on a study of melt inclusions, Fluid Inclusion Res., 9, 182-253.

Villari, L. (1980): The island of Alicudi, Rend. Soc. It Miner. Petrol., 36 (1), 441-466.

VITYK, M.O. and R.J. BoDNAR (1998): Statistical microthermometry of synthetic fluid inclusions in quartz during decompression re-equilibration, Contrib. Mineral. Petrol., 132, p. 149-162.

ZANON, V. (2001): Inclusioni fluide e vetrose negli xenoliti delle Eolie: implicazioni vulcanologiche e magmatologiche, Tesi di Dottorato, Perugia. 